\title{
Effects of cortisol and thyroid hormone on peripheral outer ring deiodination and osmoregulatory parameters in the Senegalese sole (Solea senegalensis)
}

\author{
Francisco J Arjona ${ }^{1,2}$, Luis Vargas-Chacoff ${ }^{2,3}$, María P Martín del Río ${ }^{2}$, Gert Flik ${ }^{1}$, Juan M Mancera ${ }^{2}$ \\ and Peter H M Klaren ${ }^{1}$ \\ ${ }^{1}$ Department of Animal Physiology, Institute for Water and Wetland Research, Faculty of Science, Radboud University Nijmegen, Heyendaalseweg 135 , \\ 6525 AJ Nijmegen, The Netherlands \\ ${ }^{2}$ Departamento de Biología, Facultad de Ciencias del Mar y Ambientales, Universidad de Cádiz, 11510 Puerto Real, Cádiz, Spain \\ ${ }^{3}$ Instituto de Zoología, Facultad de Ciencias, Universidad Austral de Chile, Casilla 567, 5090000 Valdivia, Chile \\ (Correspondence should be addressed to F J Arjona at Department of Animal Physiology, Institute for Water and Wetland Research, Faculty of Science, \\ Radboud University Nijmegen; Email: f.arjona@science.ru.nl)
}

\begin{abstract}
The thyroid gland in fish mainly secretes the thyroid prohormone 3,5,3',5'-tetraiodothyronine $\left(\mathrm{T}_{4}\right)$, and extrathyroidal outer ring deiodination (ORD) of the prohormone to $3,5,3^{\prime}$-triiodothyronine $\left(T_{3}\right)$ is pivotal in thyroid hormone economy. Despite its importance in thyroid hormone metabolism, factors that regulate ORD are still largely unresolved in fish. In addition, the osmoregulatory role of $\mathrm{T}_{3}$ is still a controversial issue in teleosts. In this study, we investigated the regulation of the ORD pathway by cortisol and $\mathrm{T}_{3}$ in different organs (liver, kidney, and gills) of Solea senegalensis and the involvement of $\mathrm{T}_{3}$ in the control of branchial and renal $\mathrm{Na}^{+}, \mathrm{K}^{+}$-ATPase activity, a prime determinant of the hydromineral balance in teleosts. Animals
\end{abstract}

were treated with i.p. slow-release coconut oil implants containing cortisol or $\mathrm{T}_{3}$. Hepatic and renal ORD activities were up-regulated in cortisol-injected animals. $\mathrm{T}_{3}$-treated fish showed a prominent decrease in plasma-free $T_{4}$ levels, whereas ORD activities did not change significantly. Branchial and renal $\mathrm{Na}^{+}, \mathrm{K}^{+}$-ATPase activities were virtually unaffected by $\mathrm{T}_{3}$, but were transiently up-regulated by cortisol. We conclude that cortisol regulates local $\mathrm{T}_{3}$ bioavailability in $S$. senegalensis via ORD in an organ-specific manner. Unlike $T_{3}$, cortisol appears to be directly implicated in the up-regulation of branchial and renal $\mathrm{Na}^{+}, \mathrm{K}^{+}$-ATPase activities.

Journal of Endocrinology (2011) 208, 323-330

\section{Introduction}

Thyroid hormone regulates many important functions such as growth, salinity preference, oxygen consumption, nutrient metabolism, and metamorphosis in fish (reviewed by Eales (2006) and Blanton \& Specker (2007)). Under normal conditions, the piscine thyroid gland mainly secretes the prohormone $3,5,3^{\prime}, 5^{\prime}$-tetraiodothyronine $\left(\mathrm{T}_{4}\right)$. $\mathrm{T}_{4}$ must be converted, by removal of an iodine atom, to yield the biologically active hormone $3,5,3^{\prime}$-triiodothyronine $\left(\mathrm{T}_{3}\right.$; Eales \& Brown 1993). This reaction is catalyzed by iodothyronine deiodinases, a family of selenoenzymes, of which three types exist. Deiodinases type 1 (D1) and type 2 (D2) catalyze the outer ring deiodination (ORD, or $5^{\prime}$-deiodination) pathway that converts the prohormone $\mathrm{T}_{4}$ to $\mathrm{T}_{3}$. The ORD pathway is thus of paramount importance for thyroid bioactivity in fish. Liver, gills, and kidney in particular have a high ORD capacity, and can function as an extrathyroidal source of bioactive $\mathrm{T}_{3}$ (Arjona et al. 2010).
Thyroid hormones and the steroid hormone cortisol are thought to be implicated in osmoregulation in teleosts. Cortisol is a gluco- and mineralocorticoid in fish (Mommsen et al. 1999, McCormick 2001). In teleosts acclimating to hyperosmotic environments, cortisol regulates $\mathrm{Na}^{+}, \mathrm{K}^{+}-$ ATPase activities which are prime determinants of osmoregulatory capacity (Mancera \& McCormick 2007). On the other hand, the role of thyroid hormones in osmoregulation is generally much less well investigated (Klaren et al. 2007a).

Several studies have revealed effects of glucocorticoids on thyroid hormone metabolism. Cortisol stimulated the conversion, by ORD, of $\mathrm{T}_{4}$ to $\mathrm{T}_{3}$ in Salvelinus fontinalis liver in vitro (Vijayan et al. 1988), and enhanced liver D1 and D2 activities in Fundulus heteroclitus (Orozco et al. 1998). Negative results have also been reported, i.e. for the hepatic conversion of $\mathrm{T}_{4}$ to $\mathrm{T}_{3}$ in Oncorhynchus mykiss (Brown et al. 1991). I.v. administration of the synthetic glucocorticoid dexamethasone decreased liver D1 and D2 activities in Oreochromis niloticus but left ORD unaffected in gills, kidney, 
and brain (Walpita et al. 2007). It appears that the regulation of ORD by glucocorticoids in fish depends on the species and organ assessed, and a general picture cannot be constructed.

The Senegalese sole (Solea senegalensis) is a euryhaline species that is cultured at a commercial scale in Spain and Portugal (Dinis et al. 1999). Experimental results show that, following acclimation of $S$. senegalensis to different osmotic conditions, plasma cortisol and free $\mathrm{T}_{4}\left(\mathrm{fT}_{4}\right)$ concentrations change in a concerted manner, hinting at an interaction between the hypothalamus-pituitary-inter-renal (HPI) and the thyroidal axes (Arjona et al. 2008). Moreover, during the adjustment period that follows the transfer to a different ambient osmolarity, renal and hepatic ORD activities are elevated, and plasma cortisol concentrations are increased (Arjona et al. 2008).

Whether the bidirectional communication between HPI and thyroidal axes in S. senegalensis occurs at a central and/or peripheral level is as yet unknown. We here investigate the hypothesis that cortisol and $\mathrm{T}_{3}$ affect the ORD pathway, a key metabolic route for thyroid hormones, in Senegalese sole. In particular, liver and kidney, two organs with considerable ORD capacity, and gills, the main osmoregulatory organ, were investigated. We have also analyzed $\mathrm{Na}^{+}, \mathrm{K}^{+}$-ATPase activities in gills and kidney, and plasma concentrations of glucose and lactate, which can fuel osmoregulatory processes.

\section{Materials and Methods}

\section{Fish and animal care}

Juvenile Senegalese sole ( $S$. senegalensis) with a body weight of $38 \pm 9 \mathrm{~g}$ and a total length of $150 \pm 19 \mathrm{~mm}$ (mean \pm s.D., $n=90)$ were provided by Planta de Cultivos Marinos (C.A.S.E.M., Universidad de Cádiz, Puerto Real, Cádiz, Spain). Fish were acclimated for 14 days to full strength seawater (SW, with a nominal salinity of $38 \%$ and a nominal osmolality of $1037 \mathrm{mOsm} / \mathrm{kg}$ ) in three 4001 tanks in a flowthrough system until the start of experimentation. Each tank, with a bottom surface of $0.81 \mathrm{~m}^{2}$, contained 30 fish at an initial density of $1.4 \mathrm{~kg} / \mathrm{m}^{2}$. Fish were kept under a photoperiod of $10 \mathrm{~h}$ light: $14 \mathrm{~h}$ darkness and at a constant water temperature of $18{ }^{\circ} \mathrm{C}$. Fish were fed daily with commercial dry pellets (Dibaq-Diproteg SA, Segovia, Spain) at a ration of $1 \%$ of the total body weight, and were fasted $24 \mathrm{~h}$ before sampling. This ration did not lead to detectable nitrogenous waste build-up in the tanks. The experimental procedures comply with the Guidelines of the European Union Council (86/609/EU) and of the University of Cádiz (Spain) for the use of animals in research. No mortality was observed during the experiment.

\section{Experimental design}

SW-acclimated fish were randomly divided into three groups of 27 animals. Fish were caught by netting, lightly anesthetized with $0 \cdot 05 \%$ (v/v) 2-phenoxyethanol (Sigma Chemical Co., St Louis, MO, USA.), weighed, and injected intra-peritoneally with slow-release coconut oil (Sigma Chemical Co.) implants. The injection volume was $5 \mu \mathrm{l} / \mathrm{g}$ body weight, and coconut oil was warmed to its melting point $\left(24^{\circ} \mathrm{C}\right)$ prior to injection. Experimental groups received cortisol (hydrocortisone 21 -hemisuccinate) in a dose of $50 \mu \mathrm{g} / \mathrm{g}$ body weight, or $\mathrm{T}_{3}$ $\left(3,3^{\prime}, 5\right.$-triiodo-L-thyronine, $\geq 95 \%$ HPLC quality) in a dose of $2 \mu \mathrm{g} / \mathrm{g}$ body weight. The control group received only the coconut oil implant. Hormone preparations were obtained from Sigma Chemical Co. The use of coconut oil as a vehicle for i.p. hormonal implants has been shown to be an effective and practical method to raise plasma cortisol or thyroid hormone levels in different teleost species (Laiz-Carrión et al. 2003, Morgado et al. 2007). Nine fish did not receive any treatment and served as the pre-injection group. After injection, fish were returned to three designated 4001 tanks in a flow-through system with SW that was refreshed at a rate of $50 \mathrm{l} / \mathrm{h}$. Per experimental group, nine animals were sampled on days 3,7 , and 14 post-implantation.

\section{Sampling procedures}

Fish were anesthetized in $0 \cdot 1 \%(\mathrm{v} / \mathrm{v})$ 2-phenoxyethanol and weighed. Mixed arterial and venous blood was collected from the caudal peduncle in $1 \mathrm{ml}$ heparinized syringes. Plasma was obtained by centrifugation ( $3 \mathrm{~min}$ at $10000 \mathrm{~g}$ ), immediately frozen in liquid nitrogen, and stored at $-80{ }^{\circ} \mathrm{C}$ until further analysis. After blood collection, fish were killed by spinal transection. From each fish, the first gill arch on the ocular side was excised as well as a small portion of the caudal zone of the kidney. Excess water was removed using absorbent paper, and tissues were frozen in liquid nitrogen and stored at $-80{ }^{\circ} \mathrm{C}$ until analysis of $\mathrm{Na}^{+}, \mathrm{K}^{+}$-ATPase activities. Liver, the remaining kidney, and the rest of gill arches were removed, frozen in liquid nitrogen, and stored at $-80{ }^{\circ} \mathrm{C}$ until analysis of ORD activities.

\section{Plasma parameters}

Six fish of each group were randomly selected for plasma analyses. Plasma osmolality was measured with a cryoscopic osmometer (Gonotec, Berlin, Germany). Plasma $\mathrm{Na}^{+}, \mathrm{Cl}^{-}$, $\mathrm{K}^{+}$, glucose, and lactate concentrations were measured using a Stat Profile pHOx plus analyser (Nova Biomedical, Waltham, MA, USA). Plasma cortisol was measured by RIA as described by Metz et al. (2005). Plasma-free $\mathrm{T}_{3}\left(\mathrm{fT}_{3}\right.$ ) and $\mathrm{fT}_{4}$ levels were determined by a commercially available solid-phase time-resolved fluoroimmunoassay (Wallac DELFIA from PerkinElmer Life and Analytical Sciences, Turku, Finland). Samples were diluted with charcoal-stripped plasma from SW-acclimated $S$. senegalensis prior to $\mathrm{fT}_{3}$ determinations: plasma from $\mathrm{T}_{3}$-injected fish was diluted 1:10 (v/v); plasma obtained from the other groups was diluted 1:3 (v/v). The DELFIA method has previously been validated for use with S. senegalensis plasma (Arjona et al. 2010). 


\section{Tissue preparations}

To determine $\mathrm{Na}^{+}, \mathrm{K}^{+}$-ATPase activities, gills were thawed at room temperature. Branchial tissue was obtained by scraping the gill arch with a glass microscope slide and homogenized in $1 \mathrm{ml}$ of ice-cold sucrose buffer $(250 \mathrm{mM}$ sucrose, $1 \mathrm{mM}$ EDTA, and $100 \mathrm{mM}$ trishydroxymethylaminomethane- $\mathrm{HCl}, \mathrm{pH} 7 \cdot 4$ ) in a glass dounce homogenizer equipped with a tightly fitting Teflon pestle. Kidney fragments were homogenized in $0.5 \mathrm{ml}$ sucrose buffer. To determine ORD activities, gills, liver, and the remaining kidney were homogenized in phosphate buffer $(100 \mathrm{mM}$ Na-phosphate, $2 \mathrm{mM}$ EDTA, pH 7·0). Homogenates were stored at $-80{ }^{\circ} \mathrm{C}$ until further analysis. Protein was measured with a commercial Coomassie Brilliant Blue reagent kit (Bio-Rad Laboratories) using BSA as a standard.

\section{Gill and kidney $\mathrm{Na}^{+}, \mathrm{K}^{+}$-ATPase activities}

The specific $\mathrm{Na}^{+}-$and $\mathrm{K}^{+}$-dependent, ouabain-sensitive ATPase activity was measured in triplicate in gill and kidney homogenates according to the method described by Flik et al. (1983). The method was adapted to 96-well microplate format by scaling down original volumes. Homogenates were diluted with ice-cold sucrose buffer in order to achieve maximally $<15 \%$ ATP consumption during the incubation period. Triplicate $5 \mu \mathrm{l}$ aliquots of diluted homogenates were incubated for $15 \mathrm{~min}$ at $37^{\circ} \mathrm{C}$. ATP consumption percentages were $11 \cdot 8 \pm 0 \cdot 4$ for gills and $10 \cdot 3 \pm 0 \cdot 3$ for kidney $\left(n=60\right.$, mean \pm s.E.M.). The specific $\mathrm{Na}^{+}$, $\mathrm{K}^{+}$-ATPase activity is expressed as $\mu \mathrm{mol}$ inorganic phosphate per min per mg protein.

\section{ORD activities}

ORD activities were assayed following the method described by Klaren et al. (2005). We used reverse $\mathrm{T}_{3}\left(\mathrm{rT}_{3}\right.$, $3,3^{\prime}, 5^{\prime}$-triiodothyronine) and $\mathrm{T}_{4}$ as the preferred substrates for $5^{\prime}$-deiodinases (Mol et al. 1998). The requirements of the $\mathrm{rT}_{3}$-ORD and $\mathrm{T}_{4}$-ORD reactions for dithiothreitol (DTT) in $S$. senegalensis have been determined previously (Arjona et al. 2008, 2010). As DTT inhibited ORD, it was excluded from the assay media. ORD activities were assayed in duplicate using $20-70 \mu \mathrm{g}$ homogenate protein at $37^{\circ} \mathrm{C}$ in $200 \mu \mathrm{l}$ of $100 \mathrm{mM}$ phosphate buffer ( $\mathrm{pH} 7 \cdot 0)$ to which were added: $5 \mu \mathrm{M}$ of $\mathrm{rT}_{3}$ or $\mathrm{T}_{4}$ (Sigma Chemical Co.), $10^{5}$ c.p.m. $\left[{ }^{125} \mathrm{I}\right] \mathrm{rT}_{3}$ or $\left[{ }^{125} \mathrm{I}\right] \mathrm{T}_{4}$ (NEN Life Science Products, Inc., Boston, MA, USA), and $2 \mathrm{mM}$ EDTA. Incubation period was set at $15 \mathrm{~min}$ for $\mathrm{rT}_{3}-\mathrm{ORD}$ and $12 \mathrm{~min}$ for $\mathrm{T}_{4}$-ORD. During this period, substrate consumption was $<10 \%$ : $\mathrm{rT}_{3}$ consumption percentages were $6 \cdot 7 \pm 0 \cdot 10$ for gills, $5 \cdot 8 \pm 0 \cdot 19$ for kidney, and $2.4 \pm 0.07$ for liver; $\mathrm{T}_{4}$ consumption percentages were $9 \cdot 1 \pm 0 \cdot 13$ for gills, $6 \cdot 4 \pm 0 \cdot 18$ for kidney, and $8 \cdot 8 \pm 0 \cdot 3$ for liver $(n=60$, mean \pm S.E.M.). Measurements were corrected for non-enzymatic ORD activity that was determined in the absence of sample. Radiotracer was purified on a $10 \%(\mathrm{w} / \mathrm{v})$ Sephadex LH-20 mini-column shortly before use, as described by Mol \& Visser (1985). The specific ORD rate was expressed as fmoles $\mathrm{rT}_{3}$ or $\mathrm{T}_{4}$ deiodinated per minute per $\mathrm{mg}$ protein. Our calculations
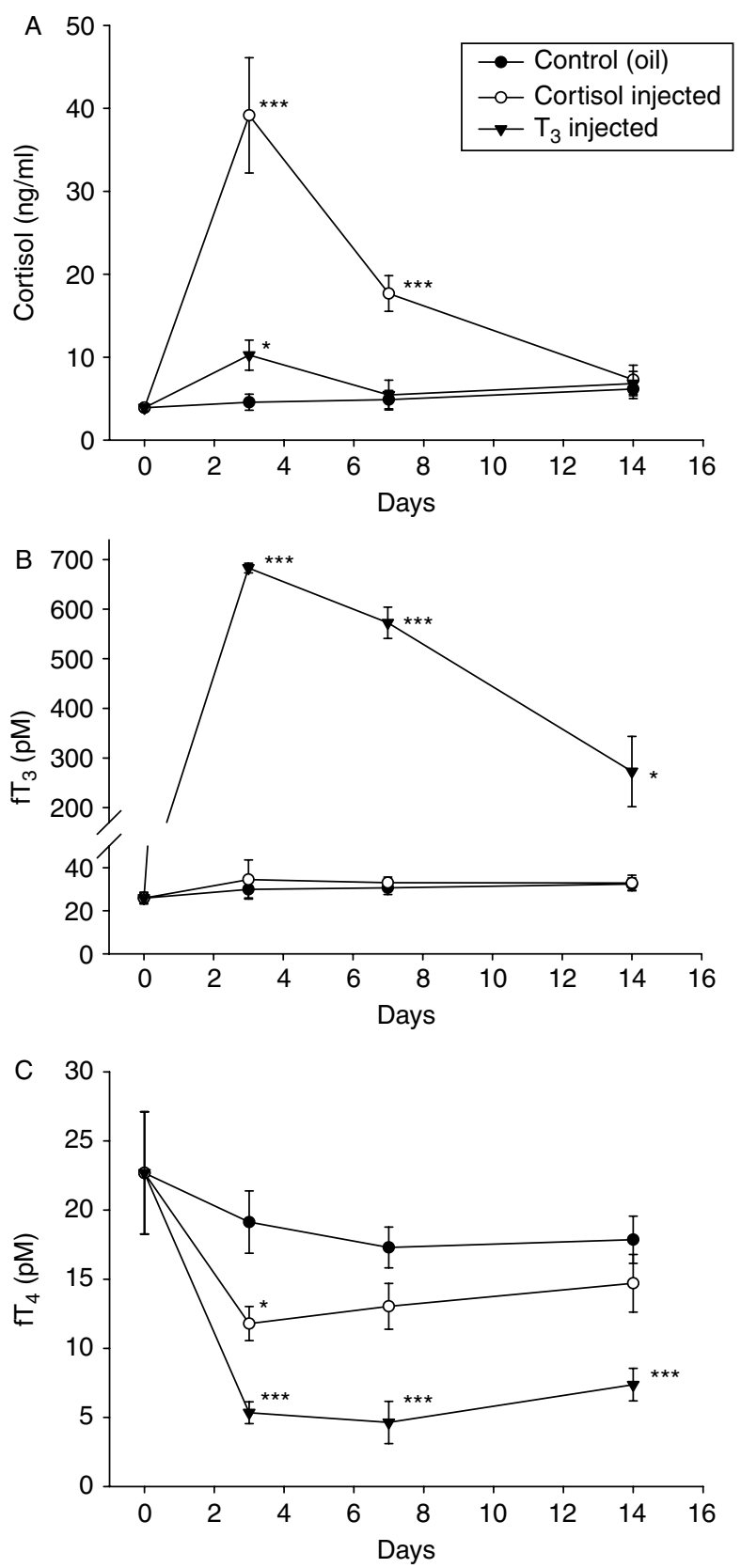

Figure 1 Time course of changes in plasma cortisol $(\mathrm{A}), \mathrm{fT}_{3}(\mathrm{~B})$, and $\mathrm{fT}_{4}(\mathrm{C})$ levels in juveniles of $S$. senegalensis after injections with coconut oil alone (control) or coconut oil containing cortisol (50 $\mu \mathrm{g} / \mathrm{g}$ body weight) or $\mathrm{T}_{3}(2 \mu \mathrm{g} / \mathrm{g}$ body weight). Values at day 0 refer to the pre-injection group. Asterisks indicate significant differences when comparing cortisol- or $\mathrm{T}_{3}$-injected groups with control groups (injected with coconut oil alone) on days 3,7 , and 14 post-implantation $\left({ }^{*} P<0 \cdot 05 ;{ }^{* * *} P<0 \cdot 001\right)$. Values are expressed as mean \pm S.E.M. $(n=5-6)$. 
included a correction factor of 2 to take into account the random radiolabeling of the $3^{\prime}$ - and $5^{\prime}$-positions of $\left[{ }^{125} \mathrm{I}\right] \mathrm{rT}_{3}$ and $\left[{ }^{125} \mathrm{I}\right] \mathrm{T}_{4}$.

\section{Statistical analysis}

Experimental groups (cortisol- or $\mathrm{T}_{3}$-injected animals) were compared with control groups (coconut oil-injected fish) on days 3, 7, and 14 post-implantation using Student's unpaired t-test or Mann-Whitney's non-parametric rank sum $U$ test, where appropriate. Statistical significance was accepted at $P<0 \cdot 05$. The same statistical analyses were applied to test the effect of the coconut oil vehicle, but here groups injected with coconut oil alone were compared with the pre-injection group.

\section{Results}

No mortality or pathologies or differences in growth rates were observed in any group throughout the experimental period. No significant differences were observed between untreated fish (pre-injection group, 0 days) and those fish implanted with coconut oil alone (controls) for any parameter assessed.

Treatment with cortisol and $\mathrm{T}_{3}$ implants effectively elevated plasma concentrations of cortisol and $\mathrm{fT}_{3}$ respectively (Fig. 1A and B). Specifically, cortisol implants elicited

Table 1 Plasma osmoregulatory and metabolic parameters in Solea senegalensis specimens injected with coconut oil alone (control) or containing cortisol ( $50 \mu \mathrm{g} / \mathrm{g}$ body weight) or $\mathrm{T}_{3}(2 \mu \mathrm{g} / \mathrm{g}$ body weight). Values are expressed as means \pm S.E.M. $(n=5-6)$

\begin{tabular}{|c|c|c|c|c|}
\hline & $\begin{array}{r}\text { Days post- } \\
\text { injection }\end{array}$ & $\begin{array}{c}\text { Control } \\
(\text { oil })\end{array}$ & Cortisol & $\mathbf{T}_{3}$ \\
\hline \multicolumn{5}{|l|}{$\begin{array}{c}\text { Parameters } \\
\text { assessed }\end{array}$} \\
\hline \multirow{3}{*}{$\begin{array}{l}\text { Osmolality } \\
(\mathrm{mOsm} / \mathrm{kg})\end{array}$} & 3 & $346 \pm 4$ & $335 \pm 3$ & $340 \pm 2$ \\
\hline & 7 & $350 \pm 5$ & $342 \pm 4$ & $345 \pm 3$ \\
\hline & 14 & $351 \pm 5$ & $341 \pm 1$ & $342 \pm 4$ \\
\hline \multirow{3}{*}{$\mathrm{Na}^{+}(\mathrm{mM})$} & 3 & $154 \pm 4$ & $137 \pm 2^{+}$ & $147 \pm 2$ \\
\hline & 7 & $158 \pm 4$ & $154 \pm 2$ & $153 \pm 1$ \\
\hline & 14 & $158 \pm 1$ & $157 \pm 4$ & $157 \pm 2$ \\
\hline \multirow[t]{3}{*}{$\mathrm{Cl}^{-}(\mathrm{mM})$} & 3 & $150 \pm 4$ & $139 \pm 1 *$ & $141 \pm 4$ \\
\hline & 7 & $152 \pm 5$ & $149 \pm 3$ & $149 \pm 4$ \\
\hline & 14 & $152 \pm 4$ & $150 \pm 7$ & $150 \pm 4$ \\
\hline \multirow[t]{3}{*}{$\mathrm{K}^{+}(\mathrm{mM})$} & 3 & $4 \cdot 9 \pm 0 \cdot 27$ & $3 \cdot 8 \pm 0 \cdot 14^{+}$ & $4 \cdot 3 \pm 0 \cdot 18$ \\
\hline & 7 & $3 \cdot 9 \pm 0 \cdot 27$ & $4 \cdot 4 \pm 0 \cdot 22$ & $4 \cdot 8 \pm 0 \cdot 4$ \\
\hline & 14 & $4 \cdot 2 \pm 0 \cdot 16$ & $4 \cdot 4 \pm 0 \cdot 4$ & $4 \cdot 5 \pm 0 \cdot 28$ \\
\hline \multirow{3}{*}{$\begin{array}{l}\text { Glucose } \\
\text { (mM) }\end{array}$} & 3 & $3 \cdot 7 \pm 0 \cdot 15$ & $5 \cdot 4 \pm 0 \cdot 12^{\ddagger}$ & $3 \cdot 5 \pm 0 \cdot 17$ \\
\hline & 7 & $3 \cdot 9 \pm 0 \cdot 3$ & $4 \cdot 4 \pm 0 \cdot 14$ & $3 \cdot 5 \pm 0 \cdot 18$ \\
\hline & 14 & $4 \cdot 0 \pm 0 \cdot 27$ & $4 \cdot 5 \pm 0 \cdot 14$ & $3 \cdot 7 \pm 0 \cdot 14$ \\
\hline \multirow[t]{3}{*}{ Lactate (mM) } & 3 & $3 \cdot 1 \pm 0 \cdot 08$ & $3 \cdot 3 \pm 0 \cdot 4$ & $3 \cdot 3 \pm 0 \cdot 20$ \\
\hline & 7 & $3 \cdot 5 \pm 0 \cdot 7$ & $3 \cdot 2 \pm 0 \cdot 20$ & $2 \cdot 9 \pm 0 \cdot 16$ \\
\hline & 14 & $3 \cdot 2 \pm 0 \cdot 20$ & $3 \cdot 0 \pm 0 \cdot 6$ & $3 \cdot 2 \pm 0 \cdot 27$ \\
\hline
\end{tabular}

Symbols indicate significant differences when comparing cortisol- or $\mathrm{T}_{3}$ injected groups with control groups (injected with coconut oil alone) on days 3,7 , and 14 post-implantation $\left({ }^{*} P<0 \cdot 05 ;{ }^{\dagger} P<0 \cdot 01 ;{ }^{\ddagger} P<0 \cdot 001\right)$.
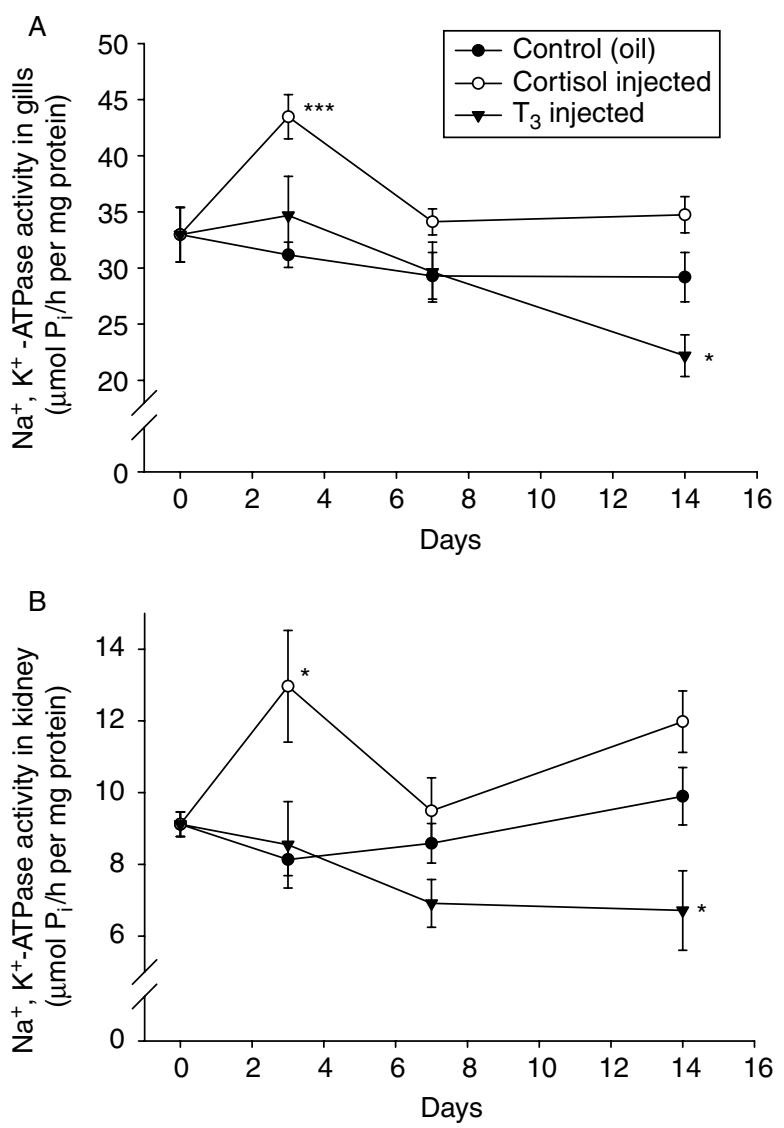

Figure 2 Time course of $\mathrm{Na}^{+}, \mathrm{K}^{+}$-ATPase activities in gills (A) and kidney $(\mathrm{B})$ in juveniles of $S$. senegalensis after injections with coconut oil alone (control) or coconut oil containing cortisol ( $50 \mu \mathrm{g} / \mathrm{g}$ body weight) or $\mathrm{T}_{3}(2 \mu \mathrm{g} / \mathrm{g}$ body weight). Values at day 0 refer to the pre-injection group. See the legend of Fig. 1 for an explanation of the symbols used. Values are expressed as mean \pm S.E.M. $(n=5-6) .{ }^{*} P<0 \cdot 05 ; * * * P<0 \cdot 001$.

a transient increase in plasma cortisol levels, while $\mathrm{T}_{3}$ treatment resulted in sustained elevated $\mathrm{fT}_{3}$ levels throughout. Treatment with $\mathrm{T}_{3}$ also produced a ca. twofold increase in plasma cortisol levels on day 3 (Fig. 1A). Both cortisol and $\mathrm{T}_{3}$ treatments decreased plasma $\mathrm{fT}_{4}$ levels (Fig. 1C), where the effect of $\mathrm{T}_{3}$ was more pronounced than that of cortisol.

Plasma $\mathrm{Na}^{+}, \mathrm{Cl}^{-}$, and $\mathrm{K}^{+}$concentrations in cortisoltreated animals decreased significantly on day 3 compared with the control group and returned to basal values from day 7 onwards (Table 1). Plasma osmolality did not vary significantly with the different experimental treatments. Cortisol treatment increased plasma glucose levels transiently on day 3 $(P<0 \cdot 001)$ but did not change plasma lactate values. Treatment with $\mathrm{T}_{3}$ did not produce statistically significant changes in plasma electrolyte, glucose, and lactate concentrations (Table 1).

Gill and kidney $\mathrm{Na}^{+}, \mathrm{K}^{+}$-ATPase activities were stable in the control fish, and reached a maximum on day 3 in the cortisol-treated fish (Fig. 2A and B), which coincided with 
the peak in plasma cortisol levels (Fig. 1A). Enzyme activities returned to control levels on day 7 . Treatment with $\mathrm{T}_{3}$ did not produce significant changes in $\mathrm{Na}^{+}, \mathrm{K}^{+}$-ATPase activities, except at the end of the experimental period (day 14) where lowered $\mathrm{Na}^{+}, \mathrm{K}^{+}$-ATPase activities were observed in gills and kidney $(P<0 \cdot 05)$.

The effects of hormone treatments on kidney, liver, and gill $\mathrm{rT}_{3}$-ORD activities were similar to the respective $\mathrm{T}_{4}$-ORD activities in these organs (Figs 3 and 4). In fish treated with cortisol, renal and hepatic ORD activities were enhanced two- to three-fold at day 3 following injection, and decreased to control levels afterwards (Figs $3 \mathrm{~A}$ and $\mathrm{B}, 4 \mathrm{~A}$ and $\mathrm{B}$ ). In $\mathrm{T}_{3}$-treated fish, we only observed a significantly decreased renal $\mathrm{T}_{4}$-ORD activity $(P<0 \cdot 01)$ on day 7 (Fig. 4A). A transient and slight decrease in branchial $\mathrm{T}_{4}$-ORD was observed in cortisol-injected fish (Fig. 4C).

\section{Discussion}

Our results demonstrate that cortisol stimulates the ORD pathway, an important peripheral source of $\mathrm{T}_{3}$, in $S$. senegalensis liver and kidney. This observation supports our hypothesis, and indicates that the activity of thyroid hormones can be regulated not only at a central level in the brain, but also peripherally in extrathyroidal tissues. No effect of cortisol was seen on ORD activity in the gills. The constitutive branchial ORD capacity is comparable in magnitude to that in liver and kidney. It could well be that the control of intracellular thyroid hormone concentrations in gills occurs by means of up- or down-regulation of the activity of $\mathrm{T}_{3}$ membrane transporters rather than de novo production of $\mathrm{T}_{3}$. The increased ORD activities in kidney and liver following cortisol treatment in S. senegalensis (Figs 3 and 4) point to these organs as important determinants of thyroid bioactivity during a stress response when plasma cortisol concentrations increase (Wendelaar Bonga 1997, Barton 2002). It also suggests that at least some of cortisol's actions, i.e. increased renal $\mathrm{Na}^{+}, \mathrm{K}^{+}$-ATPase activity and liver gluconeogenesis (as deduced from the increased plasma glucose concentrations), are mediated via $T_{3}$. Treatment with $T_{3}$ failed to produce significant changes in renal $\mathrm{Na}^{+}, \mathrm{K}^{+}$-ATPase activity or plasma glucose levels, which is consistent with the suggestion that $\mathrm{T}_{3}$ is a mediator of cortisol actions, without osmoregulatory or gluconeogenic activity per se.

A consequence of increased ORD activities is an increase in intracellular $\mathrm{T}_{3}$ availability and, hence, an increased transcription of its genomic targets. The notion of intracellular actions of locally produced $\mathrm{T}_{3}$ also helps explain why plasma $\mathrm{fT}_{3}$ concentrations were unaltered by cortisol injection. Indeed, osmotic challenges changed peripheral ORD activities in S. senegalensis and Sparus auratus but did not result in altered plasma $\mathrm{fT}_{3}$ levels (Klaren et al. 2007b, Arjona et al. 2008). In S. fontinalis, circulating $\mathrm{T}_{4}$ and $\mathrm{T}_{3}$ remained unaltered after a cortisol treatment that had increased hepatic $\mathrm{T}_{4}$-ORD activities (Vijayan et al. 1988). A plausible explanation is that traffic of $\mathrm{T}_{3}$ out of cells is regulated by the activity of membrane transporters, preventing $\mathrm{T}_{3}$ from entering plasma.

The approximately eightfold increase in plasma cortisol levels following treatment with implants is within the physiological range, as it compares very well to the stressor-induced
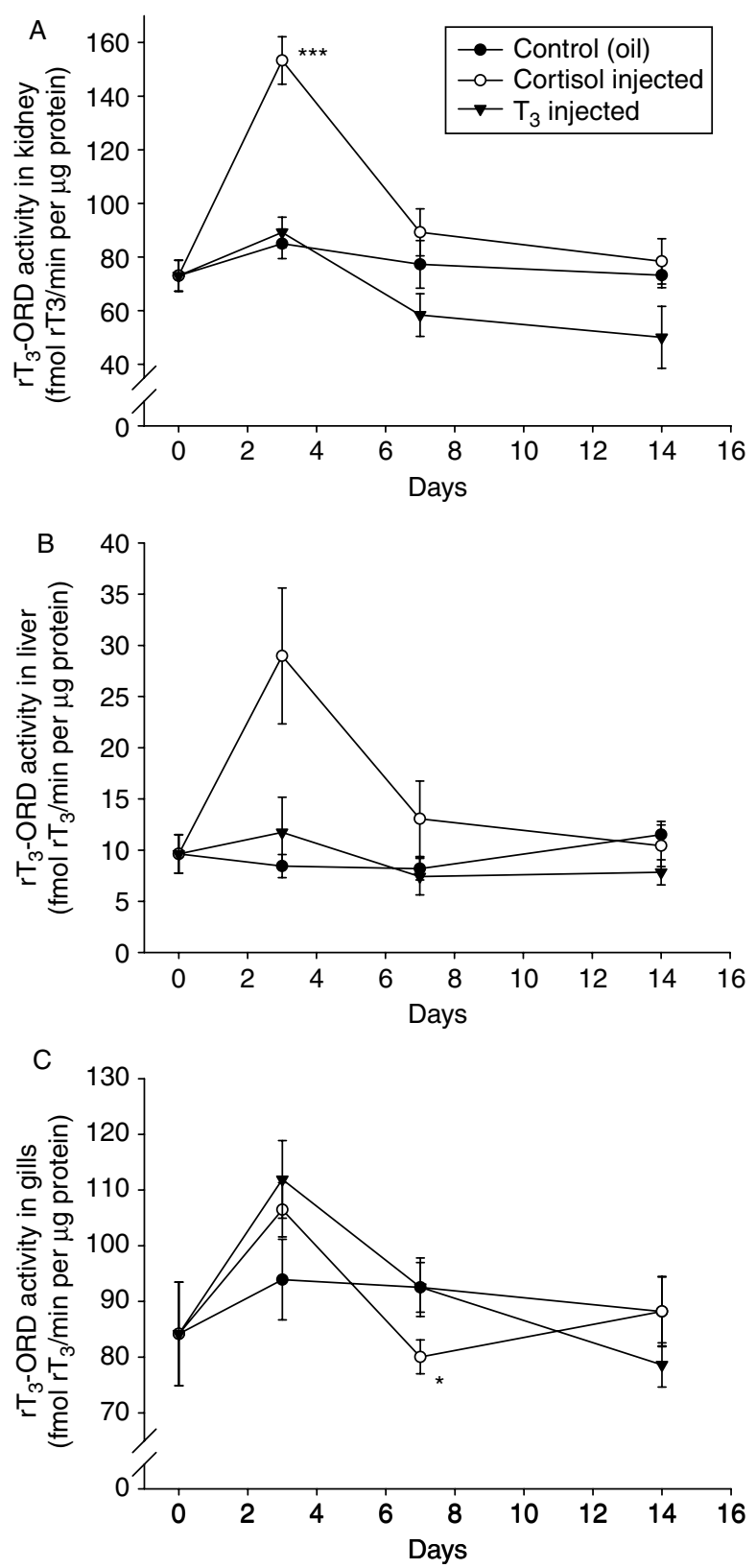

Figure 3 Time course of $\mathrm{rT}_{3}$-ORD activities in kidney (A), liver (B), and gills $(\mathrm{C})$ in juveniles of $S$. senegalensis after injections with coconut oil alone (control) or coconut oil containing cortisol (50 $\mu \mathrm{g} / \mathrm{g}$ body weight) or $\mathrm{T}_{3}(2 \mu \mathrm{g} / \mathrm{g}$ body weight). Values at day 0 refer to the pre-injection group. See the legend of Fig. 1 for an explanation of the symbols used. Values are expressed as mean \pm S.E.M. $(n=5-6) . * P<0 \cdot 05 ; * * * P<0 \cdot 001$. 

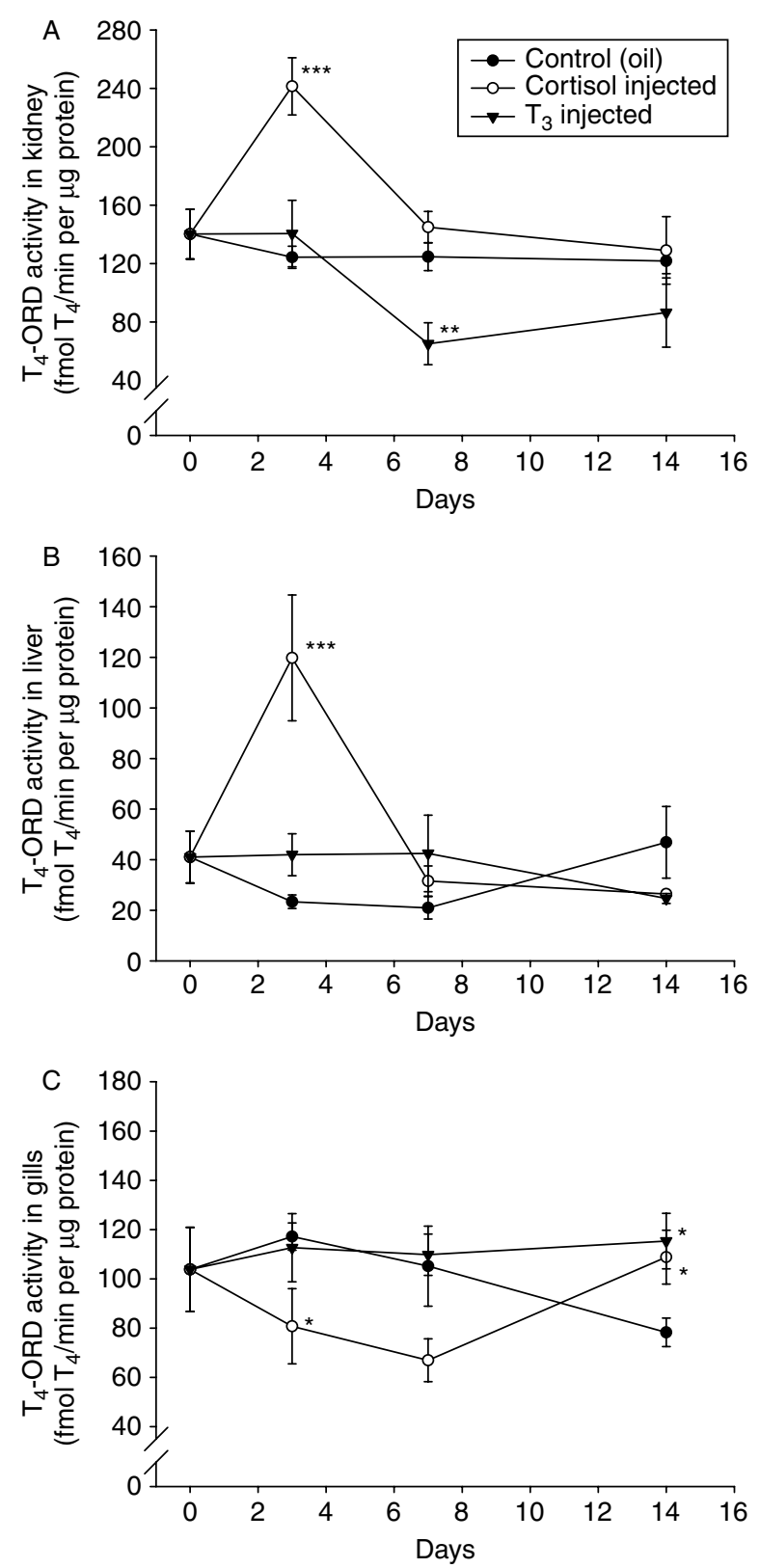

Figure 4 Time course of $\mathrm{T}_{4}$-ORD activities in kidney (A), liver (B), and gills $(C)$ in juveniles of $S$. senegalensis after injections with coconut oil alone (control) or coconut oil containing cortisol (50 $\mu \mathrm{g} / \mathrm{g}$ body weight) or $\mathrm{T}_{3}(2 \mu \mathrm{g} / \mathrm{g}$ body weight). Values at day 0 refer to the pre-injection group. See the legend of Fig. 1 for an explanation of the symbols used. Values are expressed as mean \pm S.E.M. $(n=5-6)$. ${ }^{*} P<0 \cdot 05 ; * * P<0 \cdot 01 ; * * * P<0 \cdot 001$.

4- to 40-fold increases observed in S. senegalensis and other teleost species (Woodward \& Strange 1987, Goss \& Wood 1988, van den Burg et al. 2005, Arjona et al. 2008). There are very few reports on the use of slow-release thyroid hormone implants in fishes. Morgado et al. (2007) used coconut oil to treat gilthead seabream (S. auratus) with a dose of $1 \mu \mathrm{g} \mathrm{T}_{3} / \mathrm{g}$ body weight, resulting in a 25 -fold increased $\mathrm{T}_{3}$ plasma concentration. We found a similar 27 -fold increase using a dose of $2 \mu \mathrm{g} \mathrm{T}_{3} / \mathrm{g}$. There are large differences between species in how plasma thyroid hormone levels respond to a stressor. Zebrafish (Danio rerio) can increase its plasma $T_{3}$ levels ca. 20-fold when challenged, whereas European flounder (Platichthys flesus) is refractory to a similar stimulus (Kuiper et al. 2008). We conclude that the experimentally increased plasma $\mathrm{T}_{3}$ levels reflect an upper limit of a physiological range in S. senegalensis.

Cortisol affects the metabolism of carbohydrates, proteins, and lipids in fish (Mommsen et al. 1999). In our study, cortisol produced a glucocorticoid effect in S. senegalensis, evoking a mild hyperglycemia, probably by stimulation of gluconeogenic routes in the liver (Mommsen et al. 1999). In addition to its glucocorticoid actions, the role of cortisol as a mineralocorticoid is obvious in S. senegalensis, as cortisolinjected animals showed lowered plasma $\mathrm{Na}^{+}$and $\mathrm{Cl}^{-}$levels and increased $\mathrm{Na}^{+}, \mathrm{K}^{+}$-ATPase activities in gills and kidney 3 days after injection. These results agree with the classical osmoregulatory role of cortisol in teleosts (Seidelin et al. 1999, Laiz-Carrión et al. 2003, Sherwani \& Parwez 2008).

A drop in plasma $\mathrm{fT}_{4}$ levels can be caused by a decrease in thyroidal $\mathrm{T}_{4}$ production and secretion and/or changes in peripheral metabolism (Blanton \& Specker 2007), a picture similar to that in mammals (Visser \& Fliers 2007). The decrease in plasma $\mathrm{fT}_{4}$ levels in cortisol-injected $S$. senegalensis (Fig. 1) coincided with increased ORD activities in liver and kidney and, hence, an increased $\mathrm{T}_{4}$-to- $\mathrm{T}_{3}$ conversion. However, we cannot exclude a feedback mechanism in which cortisol reduces the activity of hypothalamic corticotropin-releasing hormone $(\mathrm{CRH})$, urotensin-I (UI), and thyrotropin-releasing hormone (TRH), factors with both corticotropic and thyrotropic activities in a number of fish species (reviewed by Bernier et al. (2009)). Indeed, in salmonids and eels, CRH has thyrotropic activity in vitro (Larsen et al. 1998, Rousseau et al. 1999), and, in carp, the interaction between thyroid hormones and the HPI axis is illustrated by the up-regulation of hypothalamic crh-binding protein gene expression after $\mathrm{T}_{4}$ treatment (Geven et al. 2006). It could well be that hypothalamic factors of the HPI axis, namely CRH, UI, TRH, are altered after cortisol treatment in $S$. senegalensis and then, jointly with the hepatic and renal ORD pathway, have affected plasma $\mathrm{fT}_{4}$ concentrations.

Treatment with $\mathrm{T}_{3}$ reduced plasma $\mathrm{fT}_{4}$ levels ca. fourfold. Besides a $47 \%$ reduction measured in the kidney 7 days after injection, no major changes in peripheral ORD activities were observed. It is very likely that the reduction in plasma $\mathrm{fT}_{4}$ levels is the result of a reduced activity of the thyroid gland caused by a negative feedback of $\mathrm{T}_{3}$ on pituitary thyrotropes. As in mammals, $\mathrm{T}_{3}$ represses $t$ sh $\beta$-subunit gene expression in fish pituitaries in vitro in a classical negative feedback system (Pradet-Balade et al. 1997, Schmitz et al. 1998, Sohn et al. 1999). Moreover, thyroid hormone economy is complicated by the presence of specific thyroid hormone-binding proteins that facilitate vectorial plasma transport (reviewed by Klaren 
et al. (2007a)). Morgado et al. (2007) have shown that treatment of $S$. auratus with $\mathrm{T}_{3}$ increases the plasma concentration of the thyroid hormone-binding protein transthyretin ca. threefold. The concentration of free thyroid hormone levels in the plasma is a complex balance of hormonogenesis in the thyroid gland and the concentration of circulating binding proteins.

In $S$. senegalensis, $\mathrm{T}_{4^{-}}$and $\mathrm{rT}_{3}$-ORD activities were mainly unaltered after $\mathrm{T}_{3}$ treatment (Fig. 4). In some teleost species, deiodinase activity seems to be regulated by its iodothyronine substrate (Orozco et al. 1997, 2003, Sanders et al. 1997, Valverde-R et al. 1997). The ORD assays as performed in this study do not allow the discrimination between the $5^{\prime}$-deiodinases D1 and D2. Using $\mathrm{rT}_{3}$, we have tested an iodothyronine that is the preferred substrate for many vertebrate $\mathrm{D} 1$ enzymes. $\mathrm{T}_{4}$ is the preferred substrate for many deiodinases type 2 , but, more importantly, is also the physiologically relevant iodothyronine since it is the endogenous prohormone that needs to be activated by ORD. Our results show that peripheral ORD is not responsive to in vivo $\mathrm{T}_{3}$ treatment. Instead, cortisol appears to be a key regulator of peripheral ORD activity and, hence, extrathyroidal $\mathrm{T}_{3}$ production in $S$. senegalensis.

This work confirms and extends previous results (Arjona et al. 2008), and provides evidence for the involvement of cortisol in the regulation of the ORD pathway in $S$. senegalensis in an organ-specific manner as well as in physiological processes related to the hydromineral balance.

\section{Declaration of interest}

The authors declare that there is no conflict of interest that would prejudice the impartiality of the research reported.

\section{Funding}

This work was supported by the Ministerio de Ciencia e Innovación and FEDER (Spain, grant number AGL2007-61211/ACU); the Consejería de Innovación, Ciencia y Empresa (Junta de Andalucía, Spain, grant number PO7-RNM-02843); and by a pre-doctoral grant to Francisco Jesús Arjona within the program Formación de Profesorado Universitario from the Ministerio de Ciencia e Innovación (Spain, grant number AP-2004-6829).

\section{Acknowledgements}

The authors are very grateful to Planta de Cultivos Marinos (C.A.S.E.M., Universidad de Cádiz, Puerto Real, Cádiz, Spain) for providing experimental fish.

\section{References}

Arjona FJ, Vargas-Chacoff L, Martín del Río MP, Flik G, Mancera JM \& Klaren PHM 2008 The involvement of thyroid hormones and cortisol in the osmotic acclimation of Solea senegalensis. General and Comparative Endocrinology 155 796-803. (doi:10.1016/j.ygcen.2007.09.007)

Arjona FJ, Ruiz-Jarabo I, Vargas-Chacoff L, Martín del Río MP, Flik G, Mancera JM \& Klaren PHM 2010 Acclimation of Solea senegalensis to different ambient temperatures: implications for thyroidal status and osmoregulation. Marine Biology 157 1325-1335. (doi:10.1007/s00227-0101412-x)

Barton BA 2002 Stress in fishes: a diversity of responses with particular reference to changes in circulating corticosteroids. Integrative and Comparative Biology 42 517-525. (doi:10.1093/icb/42.3.517)

Bernier NJ, Flik G \& Klaren PHM 2009 Regulation and contribution of the corticotropic, melanotropic and thyrotropic axes to the stress response in fishes. In Fish Physiology, pp 235-311. Eds NJ Bernier, G Van der Kraak, AP Farrell \& CJ Brauner. New York, NY: Academic Press.

Blanton ML \& Specker JL 2007 The hypothalamic-pituitary-thyroid (HPT) axis in fish and its role in fish development and reproduction. Critical Reviews in Toxicology 37 97-115. (doi:10.1080/10408440601123529)

Brown SB, MacLatchy DL, Hara TJ \& Eales JG 1991 Effects of cortisol on aspects of 3,5,3'-triiodo-L-thyronine metabolism in rainbow trout (Oncorhynchus mykiss). General and Comparative Endocrinology 81 207-216. (doi:10.1016/0016-6480(91)90005-Q)

van den Burg EH, Metz JR, Spanings FAT, Wendelaar Bonga SE \& Flik G 2005 Plasma a-MSH and acetylated b-endorphin levels following stress vary according to $\mathrm{CRH}$ sensitivity of the pituitary melanotropes in common carp, Cyprinus carpio. General and Comparative Endocrinology 140 210-221. (doi:10.1016/j.ygcen.2004.11.010)

Dinis MT, Ribeiro L, Soares F \& Sarasquete C 1999 A review on the cultivation potential of Solea senegalensis in Spain and in Portugal. Aquaculture 176 27-38. (doi:10.1016/S0044-8486(99)00047-2)

Eales JG 2006 Modes of action and physiological effects of thyroid hormones in fish. In Fish Endocrinology, pp 767-808. Eds M Reinecke, G Zaccone \& BG Kapoor. Enfield, NH: Science Publishers.

Eales JG \& Brown SB 1993 Measurement and regulation of thyroidal status in teleost fish. Reviews in Fish Biology and Fisheries 3 299-347. (doi:10.1007/ BF00043383)

Flik G, Wendelaar Bonga SE \& FenwickJC $1983 \mathrm{Ca}^{2+}$-dependent phosphatase and ATPase activities in eel gill plasma membranes. I. Identification of $\mathrm{Ca}^{2+}$ activated ATPase activities with non-specific phosphatase activities. Comparative Biochemistry and Physiology Part B: Comparative Biochemistry 76 745-754. (doi:10.1016/0305-0491(83)90388-7)

Geven EJW, Verkaar F, Flik G \& Klaren PHM 2006 Experimental hyperthyroidism and central mediators of stress axis and thyroid axis activity in common carp (Cyprinus carpio L.). Journal of Molecular Endocrinology 37 443-452. (doi:10.1677/jme.1.02144)

Goss GG \& Wood CM 1988 The effects of acid and acid/aluminum exposure on circulating plasma cortisol levels and other blood parameters in the rainbow trout, Salmo gairdneri. Journal of Fish Biology 32 63-76. (doi:10. 1111/j.1095-8649.1988.tb05335.x)

Klaren PHM, Haasdijk R, Metz JR, Nitsch LMC, Darras VM, Van der Geyten S \& Flik G 2005 Characterization of an iodothyronine $5^{\prime}$-deiodinase in gilthead seabream (Sparus auratus) that is inhibited by dithiothreitol. Endocrinology 146 5621-5630. (doi:10.1210/en.2005-0050)

Klaren PHM, Geven EJW \& Flik G 2007 a The involvement of the thyroid gland in teleost osmoregulation. In Fish Osmoregulation, pp 35-65. Eds B Baldisserotto, JM Mancera \& BG Kapoor. Enfield, NH: Science Publishers.

Klaren PHM, Guzmán JM, Reutelingsperger SJ, Mancera JM \& Flik G 2007 b Low salinity acclimation and thyroid hormone metabolizing enzymes in gilthead seabream (Sparus auratus). General and Comparative Endocrinology 152 215-222. (doi:10.1016/j.ygcen.2007.02.010)

Kuiper RV, Vethaak AD, Cantón RF, Anselmo H, Dubbeldam M, van den Brandhof EJ, Leonards PE, Wester PW \& van den Berg M 2008 Toxicity of analytically cleaned pentabromodiphenylether after prolonged exposure in estuarine European flounder (Platichthys flesus), and partial life-cycle exposure in fresh water zebrafish (Danio rerio). Chemosphere 73 195-202. (doi:10.1016/j.chemosphere.2008.04.079)

Laiz-Carrión R, Martín del Río MP, Miguez JM, Mancera JM \& Soengas JL 2003 Influence of cortisol on osmoregulation and energy metabolism in gilthead seabream Sparus aurata. Journal of Experimental Zoology Part A: Comparative Experimental Biology 298 105-118. (doi:10.1002/jez.a.10256) 
Larsen DA, Swanson P, Dickey JT, Rivier J \& Dickhoff WW 1998 In vitro thyrotropin-releasing activity of corticotropin-releasing hormone-family peptides in coho salmon, Oncorhynchus kisutch. General and Comparative Endocrinology 109 276-285. (doi:10.1006/gcen.1997.7031)

Mancera JM \& McCormick SD 2007 Role of prolactin, growth hormone, insulin-like growth factor I and cortisol in teleost osmoregulation. In Fish Osmoregulation, pp 497-515. Eds B Baldisserotto, JM Mancera \& BG Kapoor. Enfield, NH: Science Publishers.

McCormick SD 2001 Endocrine control of osmoregulation in teleost fish. Integrative and Comparative Biology 41 781-794. (doi:10.1093/icb/41.4.781)

Metz JR, Geven EJW, van den Burg EH \& Flik G 2005 ACTH, a-MSH and control of cortisol release: cloning, sequencing and functional expression of the melanocortin-2 and melanocortin-5 receptor in Cyprinus carpio. American Journal of Physiology. Regulatory, Integrative and Comparative Physiology 289 R814-R826. (doi:10.1152/ajpregu.00826.2004)

Mol JA \& Visser TJ 1985 Synthesis and some properties of sulfate esters and sulfamates of iodothyronines. Endocrinology 117 1-7. (doi:10.1210/ endo-117-1-1)

Mol KA, Van der Geyten S, Burel C, Kühn ER, Boujard T \& Darras VM 1998 Comparative study of iodothyronine outer ring and inner ring deiodinase activities in five teleostean fishes. Fish Physiology and Biochemistry 18 253-266. (doi:10.1023/A:1007722812697)

Mommsen TP, Vijayan MM \& Moon TW 1999 Cortisol in teleosts: dynamics, mechanisms of action, and metabolic regulation. Reviews in Fish Biology and Fisheries 9 211-268. (doi:10.1023/A:1008924418720)

Morgado I, Santos CRA, Jacinto R \& Power DM 2007 Regulation of transthyretin by thyroid hormones in fish. General and Comparative Endocrinology 152 189-197. (doi:10.1016/j.ygcen.2006.12.017)

Orozco A, Silva JE \& Valverde-R C 1997 Rainbow trout liver expresses two iodothyronine phenolic ring deiodinase pathways with the characteristics of mammalian types I and II 5'-deiodinases. Endocrinology 138 254-258. (doi:10.1210/en.138.1.254)

Orozco A, Linser PJ \& Valverde-R C 1998 Salinity modifies hepatic outer-ring deiodinating activity in Fundulus heteroclitus. Annals of the New York Academy of Sciences 839 409-411. (doi:10.1111/j.1749-6632.1998. tb10815.x)

Orozco A, Villalobos P, Jeziorski MC \& Valverde-R C 2003 The liver of Fundulus heteroclitus expresses deiodinase type $1 \mathrm{mRNA}$. General and Comparative Endocrinology 130 84-91. (doi:10.1016/S0016-6480(02)00570-1)

Pradet-Balade B, Schmitz M, Salmon C, Dufour S \& Querat B 1997 Downregulation of TSH subunit mRNA levels by thyroid hormones in the European eel. General and Comparative Endocrinology 108 191-198. (doi:10. 1006/gcen.1997.6960)

Rousseau K, Le Belle N, Marchelidon J \& Dufour S 1999 Evidence that corticotropin-releasing hormone acts as a growth hormone-releasing factor in a primitive teleost, the European eel (Anguilla anguilla). Journal of Neuroendocrinology 11 385-392. (doi:10.1046/j.1365-2826.1999.00334.x)
Sanders JP, Van der Geyten S, Kaptein E, Darras VM, Kühn ER, Leonard JL \& Visser TJ 1997 Characterization of a propylthiouracil-insensitive type I iodothyronine deiodinase. Endocrinology 138 5153-5160. (doi:10.1210/en. 138.12.5153)

Schmitz M, Pradet-Balade B, Lebelle N, Dufour S \& Querat B 1998 In vitro study of the TSH subunit mRNA regulation in primary culture of pituitary cells of the European eel, Anguilla anguilla. Annals of the New York Academy of Sciences 839 466-468. (doi:10.1111/j.1749-6632.1998.tb10836.x)

Seidelin M, Madsen SS, Byrialsen A \& Kristiansen K 1999 Effects of insulinlike growth factor-I and cortisol on $\mathrm{Na}^{+}, \mathrm{K}^{+}$-ATPase expression in osmoregulatory tissues of brown trout (Salmo trutta). General and Comparative Endocrinology 113 331-342. (doi:10.1006/gcen.1998.7225)

Sherwani FA \& Parwez I 2008 Plasma thyroxine and cortisol profiles and gill and kidney $\mathrm{Na}^{+} / \mathrm{K}^{+}$-ATPase and SDH activities during acclimation of the catfish Heteropneustes fossilis (bloch) to higher salinity, with special reference to the effects of exogenous cortisol on hypo-osmoregulatory ability of the catfish. Zoological Science 25 164-171. (doi:10.2108/zsj.25.164)

Sohn YC, Yoshiura Y, Kobayashi M \& Aida K 1999 Seasonal changes in mRNA levels of gonadotropin and thyrotropin subunits in the goldfish, Carassius auratus. General and Comparative Endocrinology 113 436-444. (doi:10.1006/gcen.1998.7224)

Valverde-R C, Croteau W, Lafleur GJ Jr, Orozco A \& St Germain DL 1997 Cloning and expression of a $5^{\prime}$-iodothyronine deiodinase from the liver of Fundulus heteroclitus. Endocrinology 138 642-648. (doi:10.1210/en. 138.2.642)

Vijayan MM, Flett PA \& Leatherland JF 1988 Effect of cortisol on the in vitro hepatic conversion of thyroxine to triiodothyronine in brook charr (Salvelinus fontinalis Mitchill). General and Comparative Endocrinology 70 312-318. (doi:10.1016/0016-6480(88)90151-7)

Visser TJ \& Fliers E 2007 Thyroid hormones. In Encyclopedia of Stress, pp 743-749. Ed. G Fink. New York, NY: Academic Press.

Walpita CN, Grommen SVH, Darras VM \& Van der Geyten S 2007 The influence of stress on thyroid hormone production and peripheral deiodination in the Nile tilapia (Oreochromis niloticus). General and Comparative Endocrinology 150 18-25. (doi:10.1016/j.ygcen.2006.07.002)

Wendelaar Bonga SE 1997 The stress response in fish. Physiological Reviews 77 591-625.

Woodward CC \& Strange RJ 1987 Physiological stress responses in wild and hatchery-reared rainbow trout. Transactions of the American Fisheries Society 116 574-579. (doi:10.1577/1548-8659(1987)116<574:PSRIWA>2.0. $\mathrm{CO} ; 2)$

\section{Received in final form 6 December 2010 \\ Accepted 5 January 2011 \\ Made available online as an Accepted Preprint 6 January 2011}

